Proc. Estonian Acad. Sci. Eng., 2002, 8, 3, 162-173

\title{
Residual stresses in different thermal spray coatings
}

\author{
Harri Lille ${ }^{\mathrm{a}}$, Jakub Kõo ${ }^{\mathrm{a}}$, Priit Kulu ${ }^{\mathrm{b}}$, and Toomas Pihl ${ }^{\mathrm{b}}$ \\ a Chair of Structural Mechanics and Engineering, Estonian Agricultural University, Kreutzwaldi 5, \\ 51014 Tartu, Estonia; \{hlille, ko\}@eau.ee \\ b Department of Materials Technology, Tallinn Technical University, Ehitajate tee 5, 19086 Tallinn, \\ Estonia;pkulu@edu.ttu.ee
}

Received 4 January 2002, in revised form 1 April 2002

\begin{abstract}
By testing a thin-walled ringed coated specimen, we determined the through-thickness residual stress distribution, the modulus of elasticity, and the coefficient of thermal expansion of different flame sprayed $\mathrm{Cu}-, \mathrm{Ni}-$ and $\mathrm{Ni}-\mathrm{Al}$-based powder coatings, flame spray coatings, fused self-fluxing $\mathrm{NiCrSiB}$ alloy based coatings, and a high velocity oxy-fuel (HVOF) sprayed tungsten carbide WC-17Co coating. Residual stresses were, as a rule, slightly larger on the outer surface than at the coating-substrate interface, where they were close to adhesion strength. The highest residual compressive stresses were found in HVOF sprayed coatings which have high impact erosion wear resistance. The values of the moduli of elasticity were lower or close to the corresponding values of the basic substance of the powder used for producing the coatings, while the coefficients of thermal expansion were close to those of the basic substance.
\end{abstract}

Key words: thermal spraying, powder coating, ring specimen, strain gauge, residual stress.

\section{INTRODUCTION}

Flame spraying is an effective method for improving and modifying the mechanical properties of materials and machine parts. The laying of the coating, however, is accompanied by residual stresses in it. The use of thermally sprayed coatings is limited by cracking, spalling, bulking, and delamination. These phenomena are directly related to the magnitude of residual stresses (particularly tensile stresses), and may cause unexpected failure and contribute to the reduced service life of a coated machine part. The main cause of these stresses is the difference between the modulus of elasticity and the coefficient of thermal expansion of the coating and substrate materials.

The layer removal technique is a feasible method for determining the throughthickness distribution of the residual stress in thick (and moderately thin, 
$\sim 0.2 \mathrm{~mm})$ powder coatings. The analysis of residual stresses throughout the thickness is more informative than using the X-ray technique where only the sign and the magnitude of stresses in the outer layer of the coating are determined.

A layer removal method, using low-cost measuring equipment with an ordinary resistance strain gauge, has been developed in $\left[{ }^{1-5}\right]$ as opposed to the more costly X-ray technique proposed in $\left[{ }^{6,7}\right]$. According to this method $\left[{ }^{2}\right]$, residual stresses, the modulus of elasticity, and the coefficient of thermal expansion of coatings are determined by testing a thin-walled ringed coated specimen. It is important to determine the modulus of elasticity and the coefficient of thermal expansion in situ because all coatings are used while bonded to a substrate. Further, such a specimen is easy to machine and spray since the obtained thickness and quality of the coating are stable.

\section{MEASUREMENTS}

\subsection{Residual stresses in the coating}

Residual stresses in the layer are expressed according to the general algorithm of layer growing/removing method as a sum of initial and additional stresses $\left[^{8}\right]$. Stresses in the superficial layer are called initial stresses. Additional stresses are understood as stresses which arise in this layer when subsequent layers are applied or previous layers are removed. The coated substrate (part) is usually so rigid that residual stresses are practically equal to the initial stresses. Therefore the initial stresses are here called residual stresses.

Residual stresses are calculated by the formula, described in $\left[^{1,9}\right]$. This formula has been obtained solving the axisymmetric problem for a short cylindrical shell with surface and edge loads (Fig. 1a) within the framework of the technical shell theory $\left[{ }^{10}\right]$. When residual stresses are considered to be equal in the longitudinal and circumferential directions and the Poisson's ratio of the substrate and coating are assumed to be the same, then

$$
\sigma= \pm \frac{E_{1}}{1-\mu} \cdot \frac{h+\gamma a}{1+F} \cdot \frac{\mathrm{d} \varepsilon_{\mathrm{t}}}{\mathrm{d} a}
$$

where

$$
\begin{gathered}
F=\sqrt{\frac{3(1+\mu) f^{2}}{(1-\mu) g}} \Phi, \quad f=h^{2}+2 h a+\gamma a^{2}, \\
g=h^{4}+4 \gamma h^{3} a+6 \gamma h^{2} a^{2}+4 \gamma h a^{3}+\gamma^{2} a^{4}, \quad \gamma=E_{1} / E_{2},
\end{gathered}
$$

$E_{1}, E_{2}$ are the moduli of elasticity of the substrate and coating, respectively, $\mu$ is the Poisson's ratio, $h$ is the substrate thickness, and $\varepsilon_{\mathrm{t}}$ is the measured circumferential strain which depends on the coating thickness $a$. A positive sign is used for removal of the coating and a negative sign for applying the coating. 


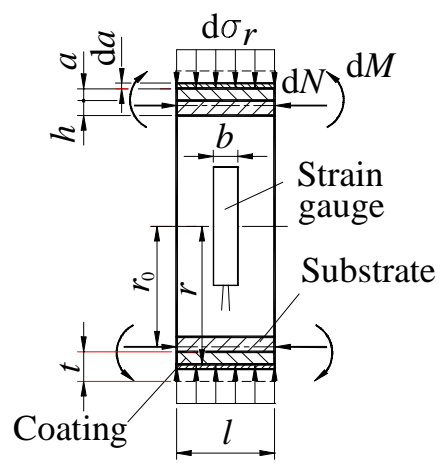

(a)

(b)

Fig. 1. External loads $\left(\mathrm{d} M, \mathrm{~d} N, \mathrm{~d} \sigma_{r}\right)$ after the removal of a superficial layer $\mathrm{d} a$ (a) and the scheme for measuring the flexural rigidity of the specimen (b).

The function $\Phi$ is

$$
\Phi=\frac{\cosh \lambda \sin \lambda \sinh \lambda^{*} \cos \lambda^{*}-\sinh \lambda \cos \lambda \cosh \lambda^{*} \sin \lambda^{*}}{\lambda^{*}(\sinh \lambda \cosh \lambda+\sin \lambda \cos \lambda)},
$$

where

$$
\lambda=\frac{\beta l}{2}, \quad \lambda^{*}=\frac{\beta b}{2}, \beta=\sqrt[4]{\frac{3\left(1-\mu^{2}\right)(h+\gamma a)^{2}}{r^{2} g}}, \quad r=r_{0}+\frac{\gamma(h+a) a}{2(h+\gamma a)},
$$

$l$ is the width of the substrate, $b$ is the width of the strain gauge, and $r_{0}$ is the middle radius of the substrate.

The problem is how to find the approximate analytical expression for $\varepsilon_{\mathrm{t}}$ on the basis of experimental data, because the formula for determining residual stresses (1) contains the derivative of $\varepsilon_{\mathrm{t}}$ (which has often both a positive and a negative sign within one experiment) relative to the coating thickness $a$. However, in mathematical terms, the derivative is a local phenomenon. Our attention is focused on the determination of the interfacial stress state, expected to be the dominant factor affecting adhesion. It follows that although the analysis of stresses in the coating is not strictly accurate, it still facilitates improvement of the spraying technology and the quality of the coating and contributes to a better understanding of the bases for the formation of a strong bond. In this case, the following analytical expression is used to approximate the experimental data

$$
\varepsilon_{\mathrm{t}}=\varepsilon_{0} \frac{c \zeta-2 \sin c \zeta}{c-2 \sin c}
$$

where $c$ is a dimensionless parameter, $\zeta=a / t, t$ is the total thickness of the coating, and $\varepsilon_{0}$ is the measured deformation when the whole coating is removed $(\zeta=1)$. 


\subsection{Modulus of elasticity of the coating}

To determine the modulus of elasticity, the technique described in $\left[{ }^{11}\right]$ was adapted. The change in the specimen diameter $\delta$, resulting from the diametrically applied load $F$ (Fig. 1b), was measured. It was assumed that the modulus of elasticity is the same throughout the coating thickness. The modulus of elasticity of the coating is

$$
E_{2}=\frac{\mathrm{d} B(a)}{\mathrm{d} I(a)} .
$$

Here $B(a)=E_{\mathrm{c}} I(a)$ is the flexural rigidity, $I(a)=l(h+a)^{3} / 12$ is the moment of inertia, and $E_{\mathrm{c}}$ is the modulus of elasticity of the composite (substrate + coating). The flexural rigidity is determined by $B(a)=0.1488 \mathrm{Fr}^{3} / \delta$, where $r$ is the middle radius of the coated ring.

\subsection{Coefficient of thermal expansion of the coating}

To determine the coefficient of thermal expansion of the coating, the specimen was heated in a thermostat. The circumferential strain $\varepsilon_{\mathrm{t}}^{T}$ of the inner surface of the specimen with and without the coating, corresponding to the temperature change $\Delta T=90^{\circ} \mathrm{C}$, was measured. Then the coefficient of thermal expansion was calculated as follows:

$$
\alpha_{2}=\alpha_{1}+\frac{\varepsilon_{\mathrm{t}}^{T}(h+\gamma t)}{\gamma t \Delta T K},
$$

where $\alpha_{1}$ is the coefficient of thermal expansion of the substrate (which is known) and

$$
K=1+\frac{h(h+t)}{f} F
$$

\section{SPECIMEN PREPARATION}

Specimens for measuring the residual stress were prepared from steel cylinders or tubes with a carbon content of about $0.3 \%$ (the modulus of elasticity was $1.98 \times 10^{5} \mathrm{~N} / \mathrm{mm}^{2}$ and the coefficient of thermal expansion $1.16 \times 10^{-5}{ }^{\circ} \mathrm{C}$ ), with an outer diameter of $32 \mathrm{~mm}$; the inner diameter of tubes was 30 and length $100 \mathrm{~mm}$. The substrate was machined to size on the lathe at the cutting speed of $v_{c}=50 \mathrm{~m} / \mathrm{min}$; cutting feed was $0.2 \mathrm{~mm} / \mathrm{r}$ and final chip thickness $0.1 \mathrm{~mm}$. The substrate surface was activated by blasting before spraying. The coating was flame sprayed onto the substrate, fixed in the rotator at the rotating speed $v_{f t}=1.6 \mathrm{~m} / \mathrm{min}$, while the gas-flame torch, positioned at the distance of $200 \mathrm{~mm}$ from the substrate, was moved longitudinally at the speed of $0.3 \mathrm{~m} / \mathrm{min}$, and the 
desired coating thickness was obtained in the course of 4 and 5 operations with or without a subsequent melting of each layer (except in the HVOF process). The coatings were sprayed with and without a bond layer between the substrate and the coating material. The cross-sections of the coatings (flame sprayed CuAlFe4, flame sprayed and fused NiCr13Si4B3+25\% (WC-15Co), and HVOF sprayed WC-17Co) are shown in Fig. 2.

The final temperature of the substrate material was about $290^{\circ} \mathrm{C}$ at spraying (heated to greyish blue) and up to $730^{\circ} \mathrm{C}$ at melting (heated to dark red). The process of cooling was carried out at room temperature. The coated tubes and cylinders were ground smooth with a resin bond diamond wheel, and a thin-walled coated tube with an inner diameter of $30 \mathrm{~mm}$ was obtained from the cylinder by boring and turning (Fig. 3a). It should be noted that the cylinder is more appropriate as a substrate compared with the tube, although during the spraying process a large temperature gradient between a droplet of sprayed material and the steel substrate occurs. When the coating is sprayed on the tube, it is excessively but not uniformly overheated and considerable deformations occur after cooling.

The tube, machined from the coated bulk cylinder, was cut into rings with a bronze bond diamond cutting wheel. From 3 to 4 duplicate specimens from the middle part of each studied coating were investigated. Two strain gauges (2PKB20-200 GB, with the basic length of $20 \mathrm{~mm}$, resistance $200 \Omega$ and gauge factor

(a)

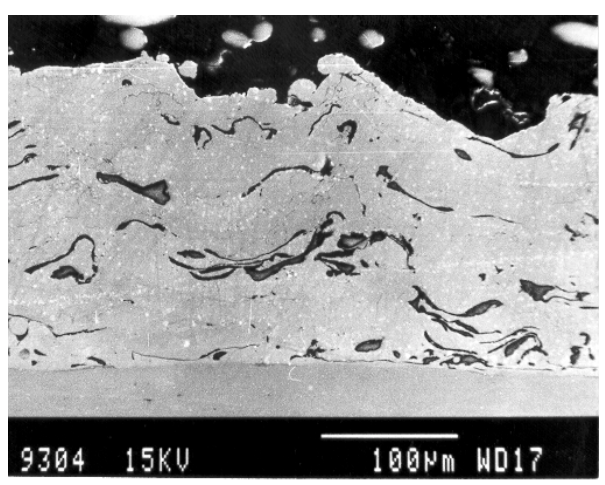

(c)

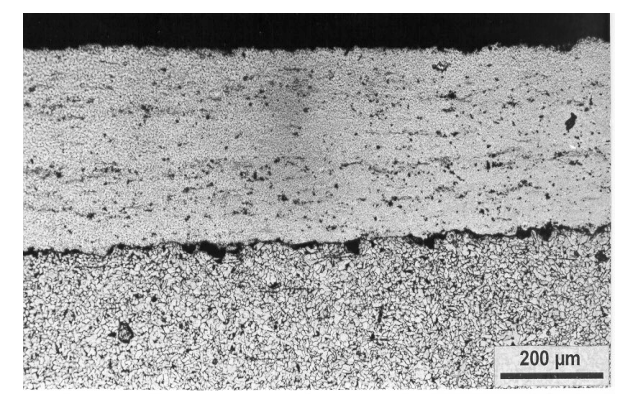

(b)

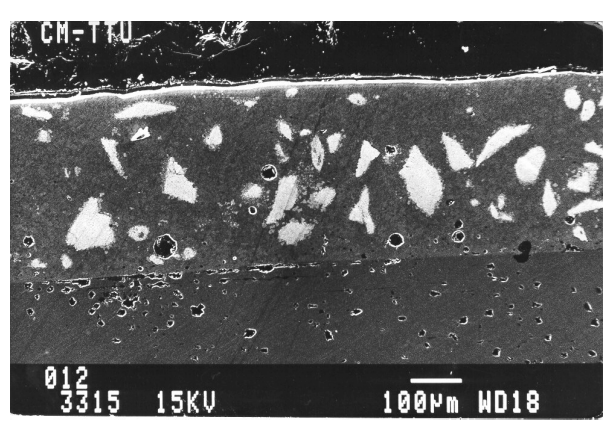

Fig. 2. Micrographs of the cross-sections of sprayed coatings: (a) flame sprayed $\mathrm{Cu}$-based coating (No. 2); (b) sprayed and fused Ni-based coating (No. 7); (c) HVOF sprayed WC-17Co coating (No. 8). 
(a)

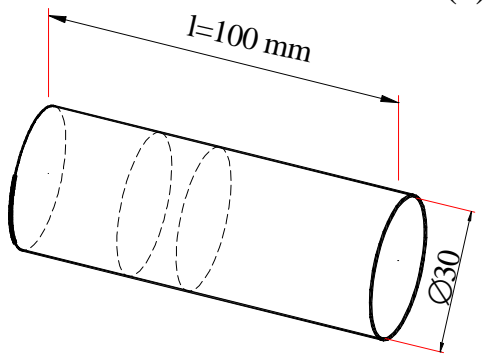

(b)

(c)

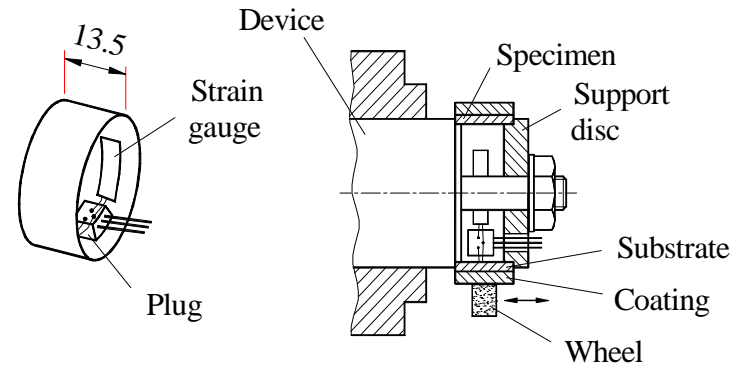

Fig. 3. A coated tube (a), a ring specimen and the position of strain gauges (b), and fixation of the specimen onto the device for layer removal (c).

2.16 at the temperature of $20 \pm 1{ }^{\circ} \mathrm{C}$, Mechanical Company of Topki, Russia) were glued to the middle of the ring in the circumferential direction (Fig. 3b). The specimen was fixed onto the device which was in the chuck of the lathe and a layer was ground with a grinding wheel under the following conditions: $v_{f t}=40 \mathrm{~m} / \mathrm{min}$, cutting speed $v_{c}=27.5 \mathrm{~m} / \mathrm{s}$, cutting feed $0.01 \mathrm{~mm} / \mathrm{r}$ (Fig. $3 \mathrm{c}$ ). The desired thickness of the removed layer depends on the material and on the coating thickness (Table 1).

Table 1. Data about coating materials, application process, and thickness of chips of the removed layer

\begin{tabular}{|c|c|c|c|c|c|c|c|}
\hline \multirow[t]{2}{*}{$\overline{\mathrm{No}}$} & \multirow{2}{*}{$\begin{array}{l}\text { Coating material } \\
\text { and code }\end{array}$} & \multirow{2}{*}{$\begin{array}{c}\text { Material } \\
\text { of the bond } \\
\text { layer }\end{array}$} & \multirow{2}{*}{$\begin{array}{l}\text { Method of } \\
\text { deposition }\end{array}$} & \multirow[t]{2}{*}{ Substrate } & \multicolumn{2}{|c|}{ Thickness, mm } & \multirow{2}{*}{$\begin{array}{c}\text { Thickness of } \\
\text { chips, } \\
\mu \mathrm{m}\end{array}$} \\
\hline & & & & & $\begin{array}{l}\text { Bond } \\
\text { layer }\end{array}$ & $\begin{array}{l}\text { Coa- } \\
\text { ting }\end{array}$ & \\
\hline 1 & $\begin{array}{l}\text { NiCr11Si2B2 } \\
\text { (PT-19N-01)* }\end{array}$ & $\begin{array}{l}\text { NiAl5 } \\
\text { (PT-NA-O1) }\end{array}$ & $\begin{array}{l}\text { Flame-spray } \\
\text { (FS) }\end{array}$ & tube & $\sim 0.15$ & 0.5 & $2 \times 35+1 \times 10$ \\
\hline 2 & $\begin{array}{l}\mathrm{CuAl10Fe} 4 \\
(\mathrm{PG}-19 \mathrm{M}-01)^{*}\end{array}$ & $\begin{array}{l}\mathrm{NiAl} \\
\text { (PT-NA-O1) }\end{array}$ & Flame-spray & cylin & $\sim 0.15$ & 1.0 & $2 \times 45+1 \times 10$ \\
\hline 3 & $\begin{array}{l}\text { NiCr16 Si3 B3 } \\
\text { (PG-SR3) }\end{array}$ & no & $\begin{array}{l}\text { Spray and } \\
\text { fusion (FSF) }\end{array}$ & tube & - & 0.9 & $2 \times 45+1 \times 10$ \\
\hline 4 & $\begin{array}{l}\text { NiCr17Si4B3 } \\
\text { (PG-10N-01)* }\end{array}$ & no & $\begin{array}{l}\text { Spray and } \\
\text { fusion }\end{array}$ & cylin & - & 1.15 & $2 \times 45+1 \times 10$ \\
\hline 5 & $\begin{array}{l}\text { Ni Al15 } \\
\text { (intermetallide) }\end{array}$ & nc & Flame-spray & tul & - & 0.3 & $2 \times 20+1 \times 10$ \\
\hline 6 & Ni Al5 & 110 & $\begin{array}{l}\text { Flame s } \\
\text { flexible }\end{array}$ & tube & - & 0.5 & $2 \times 45+1 \times 10$ \\
\hline 7 & $\begin{array}{l}\text { NiCr13Si4B3 } \\
(12495)^{* *}-25 \% \\
\text { (WC-15Co) }\end{array}$ & no & $\begin{array}{l}\text { Spray and } \\
\text { fusion }\end{array}$ & cylinder & - & 1.0 & $2 \times 20+1 \times 10$ \\
\hline 8 & $\begin{array}{l}\text { WC-17Co } \\
(1343)^{* * *}\end{array}$ & no & HVOF spray & cylinder & - & 0.2 & $2 \times 10+1 \times 5$ \\
\hline
\end{tabular}

\footnotetext{
* Powders of Toiez (produced under the licence of Castolin SA)

** Powder of Castolin SA

*** Powder of Tafa Inc.
} 
(a)

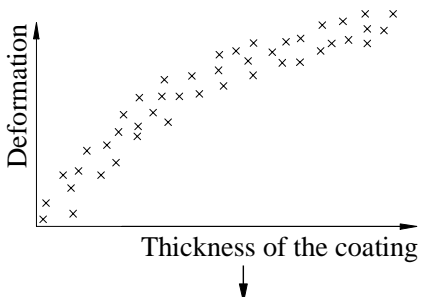

(b)
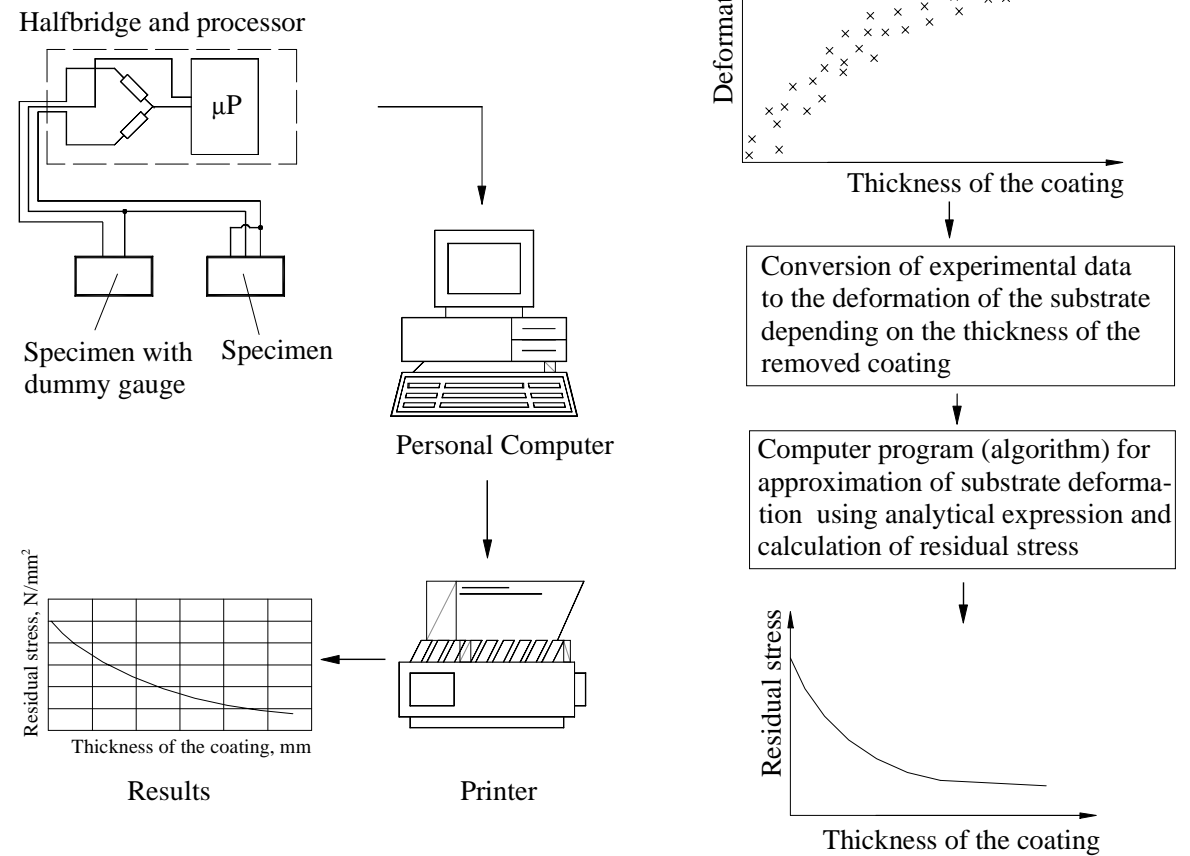

Fig. 4. Measuring system (a) and basic scheme for the determination of the residual stress (b).

The circumferential deformation was measured and stored by a strain indicator equipped with a processor. The data were entered into the computer as experimental information for calculating residual stresses (Fig. 4).

The change in the specimen diameter, resulting from the diametrically applied calibrated weights $F=49.5 \mathrm{~N}$, was measured with a dial gauge after the removal of each layer (Fig. 3b).

\section{RESULTS}

The method described was used to determine the residual stress profile of the coating, the moduli of elasticity and the coefficient of thermal expansion of coating materials. Experimental results are presented with special emphasis on the determination of residual stresses in the coatings and on their modulus of elasticity, using $\mathrm{Cu}$-based powder with bond coating (powder No. 2), two selffluxing Ni-based alloy powders (powders No. 4 and 7, reinforced with $25 \mathrm{wt} \%$ tungsten carbide based hardmetal powder particles with size of 125 to $180 \mu \mathrm{m}$, produced by desintegrator technology $\left.\left[{ }^{12}\right]\right)$, and HVOF-sprayed tungsten carbide powder WC-17Co (powder No. 8). 
As our experimental data fluctuated in a wide range, in order to obtain more reliable results the data of three to five specimens were approximated and the mean values of residual stresses and those of the moduli of elasticity were calculated using the program Mathcad 7 Professional $\left[{ }^{13}\right]$ with the smoothing functions linfit $(v x, v y, F)$ and genfit $(v x, v y, v g, F)$, respectively. Experimental data is presented in Figs. 5 to 7 and summarized in Tables 2 and 3.

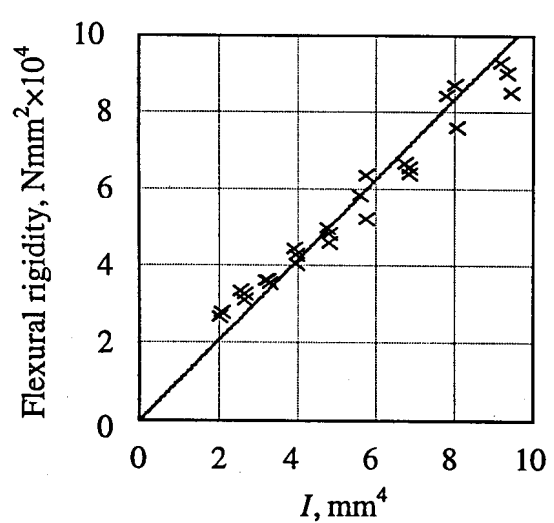

(a)

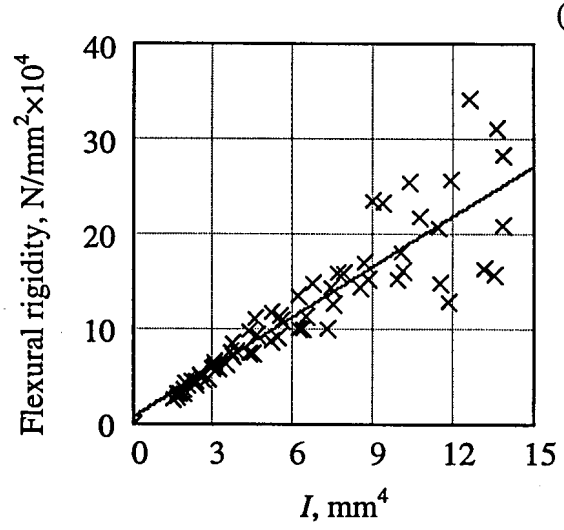

(b)

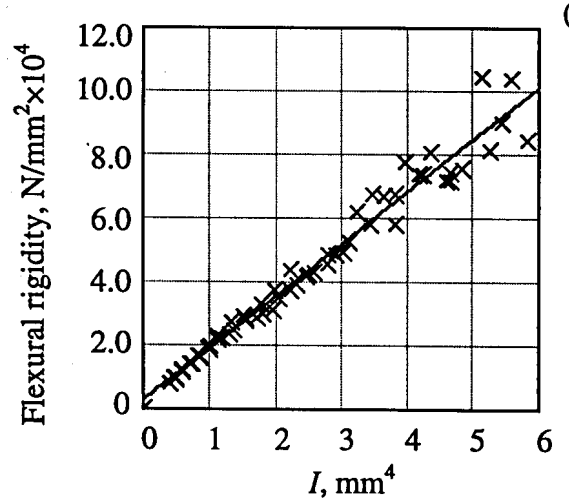

(c)

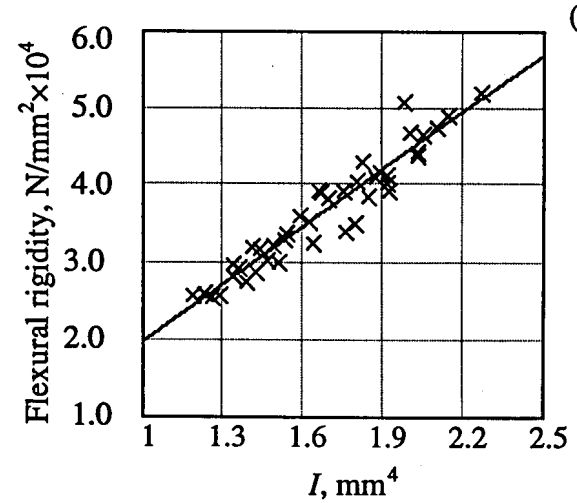

(d)

Fig. 5. Experimental values of flexural rigidity depending on the coating thickness (moment of inertia), and the lines of approximation: (a) flame sprayed Cu-based coating (No. 2); (b) sprayed and fused Ni-based coating (No.4); (c) the same with reinforcements of (WC-Co) (No.7); (d) HVOF sprayed WC-17Co coating (No. 8). 
(a)
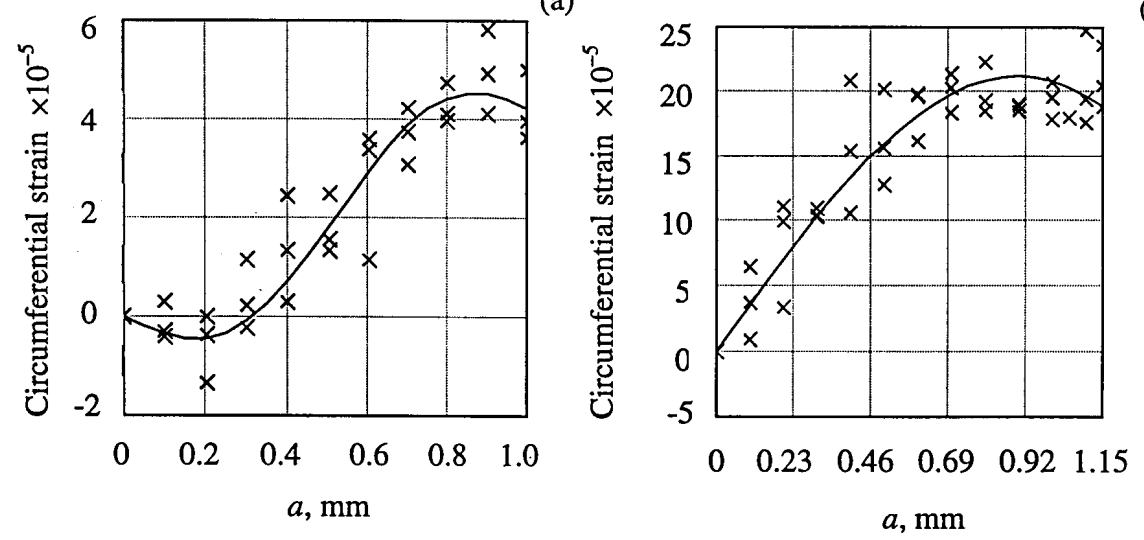

(b)

(c)

(d)
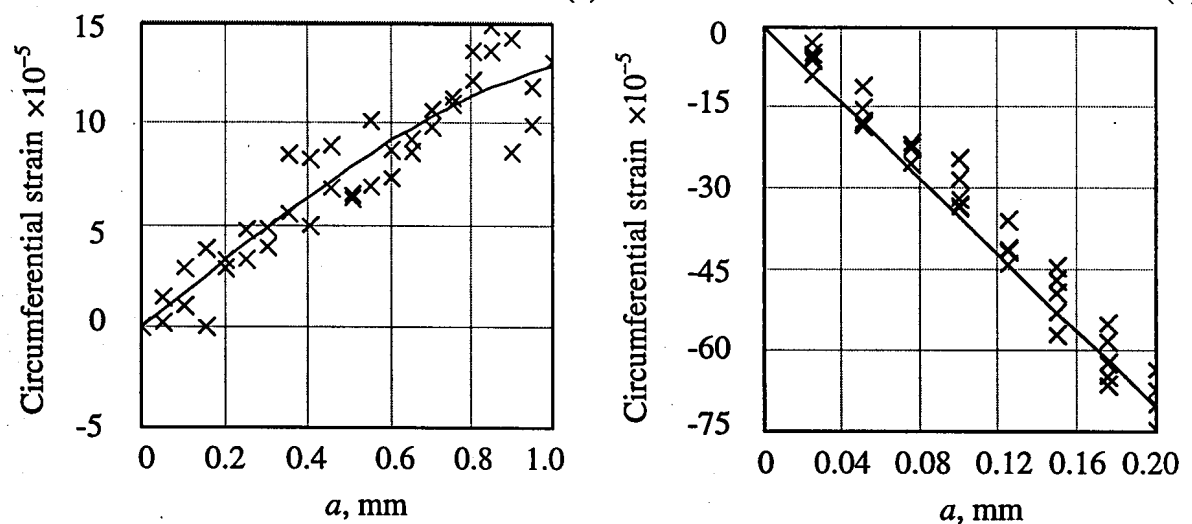

Fig. 6. Experimental values of the circumferential strain $\varepsilon_{\mathrm{t}}$ depending on the coating thickness $a$, and the curves of approximation: (a) flame sprayed Cu-based coating (No. 2); (b) sprayed and fused Ni-based coating (No. 4); (c) the same with reinforcements of WC-Co (No. 7); (d) HVOF sprayed WC-17Co coating (No. 8).

Table 2. Residual stresses, modulus of elasticity, and coefficient of thermal expansion (CTE)

\begin{tabular}{l|c|c|r|r|r|c|c}
\hline \multirow{2}{*}{ No } & \multicolumn{2}{|c|}{$\begin{array}{c}\text { Parameters of the } \\
\text { empirical expression }\end{array}$} & \multicolumn{3}{|c|}{$\begin{array}{c}\text { Residual stress } \sigma, \\
\mathrm{N} / \mathrm{mm}^{2}\end{array}$} & $\begin{array}{c}\text { Modulus of } \\
\text { elasticity } \\
E_{2} \times 10^{4}, \\
\mathrm{~N} / \mathrm{mm}^{2}\end{array}$ & $\begin{array}{c}\mathrm{CTE} \\
\alpha_{2} \times 10^{-5} \\
1 /{ }^{\circ} \mathrm{C}\end{array}$ \\
\cline { 2 - 5 } & $\varepsilon_{0} \times 10^{-5}$ & $\mathrm{c}$ & $\begin{array}{c}\text { Outer } \\
\text { layer }\end{array}$ & $\begin{array}{c}\text { Interface } \\
\text { layer }\end{array}$ & $\begin{array}{c}\text { Max } \\
\text { value }\end{array}$ & \\
\hline 1 & 8.835 & 0.855 & 11.2 & 40.4 & 40.4 & 5.5 & - \\
2 & 4.240 & -6.028 & -10.4 & -5.8 & 24.7 & 9.8 & 1.440 \\
3 & -9.600 & 0.114 & -49.0 & -19.2 & -49.0 & 21.7 & - \\
4 & 18.890 & 1.335 & -63.5 & 70.1 & 70.1 & 17.6 & 1.204 \\
5 & -11.220 & 0.043 & -61.7 & -65.8 & -65.8 & 7.1 & - \\
6 & -9.441 & 0.783 & -40.0 & -18.0 & -40.0 & 11.2 & 1.233 \\
7 & 12.870 & 0.856 & 11.8 & 25.7 & 26.8 & 16.3 & 1.174 \\
8 & -70.450 & 0.054 & -699.0 & -592.0 & -699.0 & 24.6 & 0.450
\end{tabular}



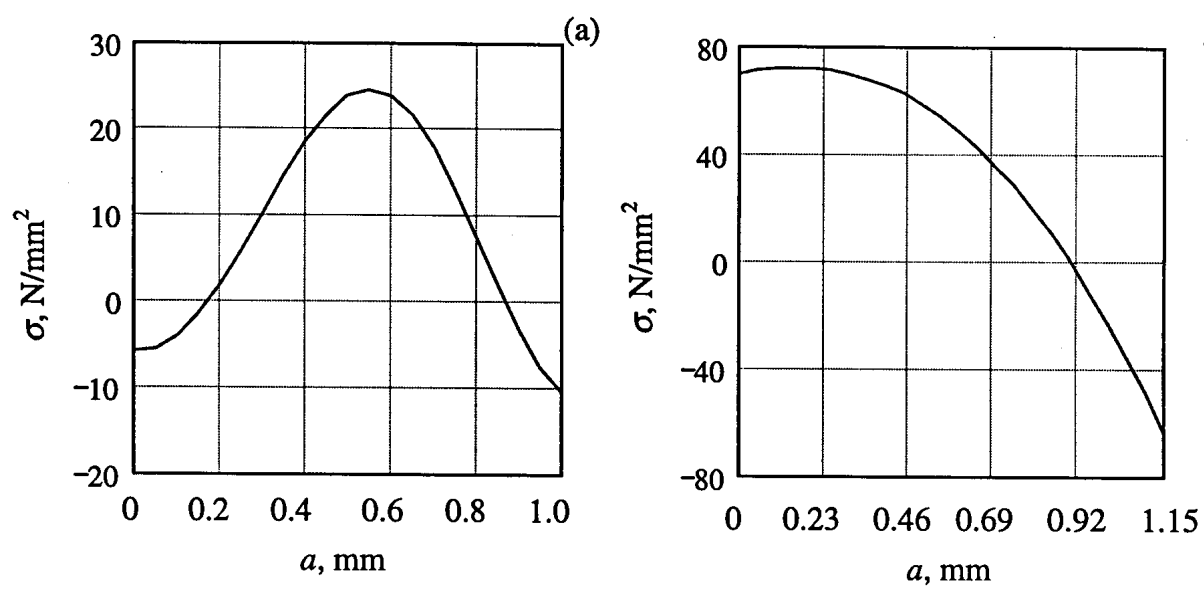

(b)

(c)
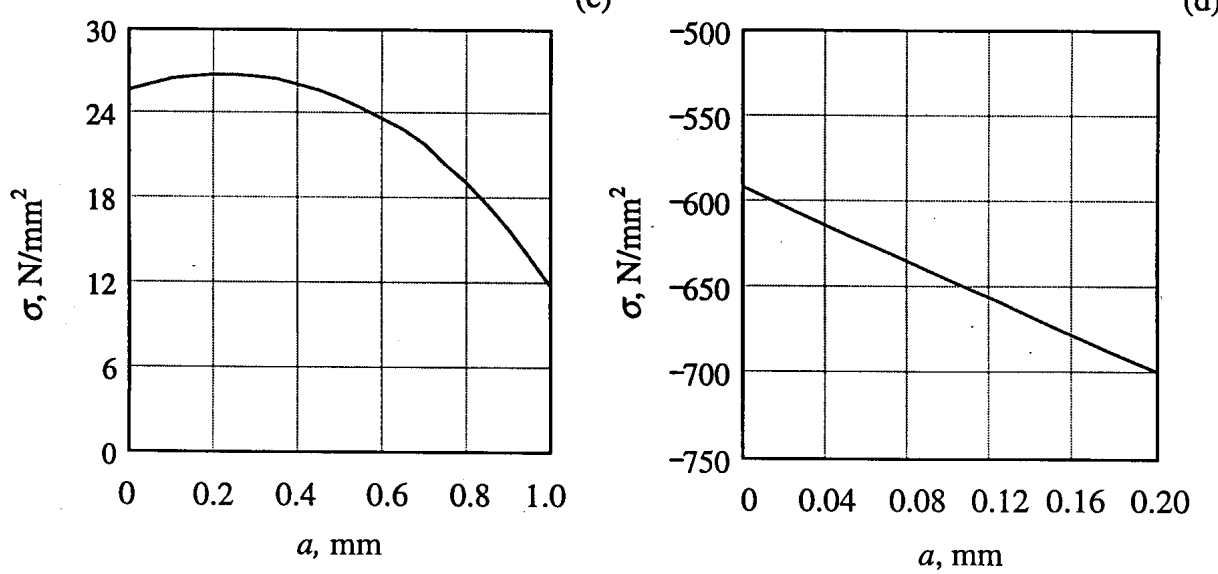

Fig. 7. Dependence of residual stresses $\sigma$ on the coating thickness $a$ : (a) flame sprayed Cu-based coating (No. 2); (b) sprayed and fused Ni-based coating (No. 4); (c) the same with reinforcements of WC-Co (No. 7); (d) HVOF sprayed WC-17Co coating (No. 8).

Table 3. Properties and abrasive-erosive wear resistance of thermal sprayed coatings

\begin{tabular}{cc|c|c|c|c|c|c}
\hline \multirow{2}{*}{$\begin{array}{c}\text { No of the } \\
\text { coating, } \\
\text { deposition } \\
\text { method }\end{array}$} & $\begin{array}{c}\text { Porosity, } \\
\%\end{array}$ & \multicolumn{3}{|c|}{ Mechanical properties } & \multicolumn{2}{|c}{$\begin{array}{c}\text { Relative wear resistance } \\
E_{\mathrm{v}}^{* * *}\end{array}$} \\
\cline { 5 - 8 } & & $\mathrm{HV} 1$ & $\begin{array}{c}E_{2} \times 10^{4}, \\
\mathrm{~N} / \mathrm{mm}^{2}\end{array}$ & $\begin{array}{c}\sigma \text { (outer layer), } \\
\mathrm{N} / \mathrm{mm}^{2}\end{array}$ & \multicolumn{2}{|c}{$\alpha$} \\
\cline { 5 - 8 } 1 & FS & $8-10$ & 280 & 5.5 & 11.2 & 0.4 & 0.1 \\
2 & FS & $12-15$ & 210 & 9.8 & -10.4 & 0.3 & 0.1 \\
5 & FSF & $2-3$ & $600 / 750^{*}$ & 7.1 & -61.7 & 1.8 & 0.4 \\
6 & FS & $10-12$ & 230 & 11.2 & -40.0 & - & - \\
7 & FSF & $2-3$ & $755 / 1400^{*}$ & 16.3 & 11.8 & 1.9 & 0.6 \\
8 & HVOF & 2.9 & 1300 & 24.6 & -699 & 10.8 & 2.6
\end{tabular}

*Hardness of matrix/hardness of reinforcements

**Reference material - normalized steel $0.45 \% \mathrm{C}$ of hardness $200 \mathrm{HV}$, abradant - quartz sand $0.1-0.3 \mathrm{~mm}$ of hardness $1100-1200 \mathrm{HV}$, velocity of particles $80 \mathrm{~m} / \mathrm{s}$. 


\section{CONCLUSIONS}

The method presented allowed the determination of the through-thickness residual stress distribution in thermally sprayed coated materials. Based on the results, a conclusion was drawn that residual stresses, in general, represent both tensile and compressive stresses which change in the direction of the coating thickness and reach a value close to the adhesion strength at the interface of the coating and the substrate. In layers close to the free surface, residual stresses are mostly low in value and in half of the cases remain within the range of standard deviation for hoop stresses, 20 to $30 \mathrm{~N} / \mathrm{mm}^{2}$. The highest compressive residual stresses in HVOF sprayed hardmetal type coatings lead to high impact erosion wear resistance. The values of the coefficient of thermal expansion of coatings are close to those of the basic substance of the powder used in producing the coatings, while the values of the moduli of elasticity in most cases are lower.

\section{REFERENCES}

1. Kõo, J., Lille, H., and Valgur, J. Determination of residual stresses in coatings by measuring the deformation of a thin-walled ring-shaped substrate. In Abstr. Reports 13th All-Union Conference on Constructive Strength of Engines (Kuznetsov, N. D., ed.). Samara, 1991, 36 (in Russian).

2. Kulu, P., Kõo, J., Lille H., and Pihl, T. Investigation into the residual stresses in gas-flame sprayed coatings. Trans. Tallinn Techn. Univ. Tallinn, 1994, No. 741, 17-31.

3. Lille, H., Kõo, J., Kulu, P., and Pihl, T. Residual stress, modulus of elasticity and coefficient of thermal expansion of some powder coatings. In Proc. 1st International DAAAM Conference (Papstel, J. and Katalnic, B., eds.). Tallinn, 1997, 165-168.

4. Greving, D. J., Rybicki, E. F., and Shadley, J. R. Through-thickness residual stress evaluations for several industrial thermal spray coatings using a modified layer-removal method. J. Therm. Spray Technol., 1994, 3, 379-388.

5. Eckold, G. C., Lloyd-Thomas, G., and Rickerby, D. S. Stress modelling on thick and thin ceramic coatings. In Ceramics Composition and Coatings. Recent Developments and Applications: Two-day Conference, London, 1988, 1-11.

6. Mc Grann, R. T. R., Rybicki, E. F., and Shadeley, J. R. Applications and theory of the modified layer removal method for the evaluation of through-thickness residual stresses in thermal spray coated material. In Proc. 5th International Conference on Residual Stresses (Ericsson, T., Odén, M., and Andersson, A., eds.). Linköping, 1997, 2, 994-999.

7. Hornbach, D. J. New way to gage residual stresses. Adv. Mater. Proc., 1998, 8, 33-37.

8. Kõo, J. Layer-growing and layer-removing methods for residual stress analysis: General algorithm. In Proc. 4th European Conference on Residual Stresses (Denis, S., Lebrun, J. L., Bourniquel, B., Barrel, M., and Flavenot, J.-F., eds.). Cluny en Bourgogne, 1996, 1, 223 232.

9. Lille, H., Kõo, J., and Valgur, J. Determination of residual stresses in the coat deposited by brush plating. In Residual Stresses (Hauk, V., Hougardy, H. P., Macherauch, E., and Tietz, H.-D., eds.). DGM Informationsgesellscaft Verlag, Oberursel, 1993, 717-722.

10. Boyarshinov, S. V. The Basics of Machine Structural Mechanics. Mashinostroenie, Moscow, 1973 (in Russian).

11. Nikorich, P. I. and Dehtjar, L. I. Determination of the modulus of elastisity and residual stresses in the nonhomogeneous bars. Zavodsk. laborat., 1970, 9, 1116-1119 (in Russian). 
12. Kulu, P., Arensburger, D., Tymanok, A., Pihl, T., and Halling, J. Wear-resistant composite hard metal consisting coatings. In Proc. 1st International DAAAM Conference (Papstel, J. and Katalnic, B., eds.). Tallinn, 1997, 160-164.

13. Mathcad 7. User's Guide. MathSoft Inc. Cambridge, Massachusetts, 1997.

\title{
Jääkpinged erinevates termopihustatud pinnetes
}

\author{
Harri Lille, Jakub Kõo, Priit Kulu ja Toomas Pihl
}

Pindega õhukeseseinalisi rõngaid katsetades on määratud jääkpinged, elastsusmoodul ja joonpaisumistegur erinevates leekpihustatud vase, nikli ja niklialumiiniumi baasil valmistatud pulberpinnetes, leekpihustatud ja sulatatud iseräbustuva $\mathrm{NiCrSiB}$-sulami ja armeeriva kõvasulami baasil valmistatud komposiitpinnetes ning kiirleekpihustatud volframkarbiidpinnetes. Jääkpinged on üldjuhul pinde pinnal veidi suuremad kui pinde ja aluse üleminekukihis, olles väärtuselt samas suurusjärgus nakketugevusega. Suurimad survepinged on kiirleekpihustatud kõvasulampinnetes, millel on kõrge vastupanu löökerosioonkulumisele. Pinnete elastsusmoodulid on madalamad pinde saamiseks kasutatud pulbri põhikomponendi vastavatest suurustest või neile lähedased, joonpaisumistegurid on neile väga lähedased. 